We read of the ancients placing their sick and afflicted in "the high-ways and public places," that some one passing by, who, like them, had been afflicted, might tell of a remedy; you, sir, will not, therefore, I trust, object to give a place in THz LANCET to the following (merely because it is non-professionally given), and I will he as brief as I can in stating what has invariably proved with me a rcmedy, and sometimes a very quick one, in that distressing discase of the legs, varicose veins. in I have, through excessive fatigue (being sonıetimes without rest for ten or eleven rights together), been very subject to varicose veins; and, duning tho period of twenty-five years past, I have met with a rreat number of females in like manner afhicted. All these, as well as myself, have been cured, whenever placed upon an insolated stool, and had the electric sparks drawn from the leg along the veins affected, beginning at the extremity of the swelling of the veins. Cinder this mode the swellings soon subside, without erer refuiring a bandage. For me, in my business, this is an unspeakalle advantage, for I could not do to be bandayed, and, nithont electricity i think I could not long follow my busines, for whencver I to have nerlected to have recourse to it in rime, I have found, that although the vein itself dill not ripture, a wound wonld begin to form even at a distance from that pari of the rein most affected, and most likely to burst. The sisin of a distant part of the leg will, in some instances, be abraded withont any visible carse, and a thin ichor run from the part, a part which, to a superficial observer, would appear to have un comexion whaterer with the raricose veins; bne spark the veins and restor 3 then to a healthy stake, and this womd inmediately skins over and becomes somnl.

With a riew of keeping my promisa of "brevity," I shall only adl, that in cases shere, unhappily, deep ulcers have been former, the "woolen point," so called, must be usel, for I have known instances where it has becn used with rery great effect; it ccols the wound and brings on a disposition to heal, $b y$ the wound secreting a much more laudahlc species of matter.

I am, Sir, yours, very respectfully,

Frixces Sirpsox,

A Mirluife, and formoly a Papil of the late: Dr. Thynn.

Leicester, March 26th, 1834.

\section{CONSTIPATION CURED WITH THE STOMACH PUMP.}

\section{To the Editor of The LANCET.}

SrR,-At the request of my friends, $I$ forward you the following particulars of $a$ case of severe constipation, that has re. cently occurred in my practice, for insertion in your valuable LANCET. It occurred in a robust elderly sailor, and had resisted, I believe, every attempt at relief,-bleeding, injections, warm-baths, croton oil, castor oil, elaterinm, and blistcring. I cured the patient by introducing the tube of a stomach-pump, two feet one inch in length, into the stomach, and working it in the usual manner, without causing pain or inconvenience to the man. On raising the piston the fourth time, it brought up fecal matter, and continued to do so till I had extracted more than a quart. On withdrawing the pipe, he was enabled to void his fxees per anum, and specdily recovered from a hastily approaching dissolution. I had introdnced the largest-sized rectum bourie three tines, without mesting with interruption to its passage, showing apparently that the cause of obstruction was beyond surgical reach. I am, Sir, your obedient servant, Aj.ERED Davis, M.R.C.S.I,

\section{Cerne Abbas, Dorsetshire,} 27 th Warch, 183t,

\section{FXERCIS OF THE ITET INARD。}

\section{To the Editor of The LAverT.}

Sin,-The celebiated Mr. Hmter is represented by Sir Charles Bell to have said, "Give a part its natural use, and that use will be its stimulus to attaining perfection,"-an observation that scems consonant with practical experience; for there can be no doubt that the healthy excreise of any member of the human frame is highly conducive to the perfection of such member.

The deficiency of strength and activity in the left arm and hand compared with the right, is sufficiently illustrative of such an opinion. There is a much greatcr equality of efficiency between the two leogs and fret, than there is betwc en the two arms and hands, which arises frun their more equal exercise. Such being the fact, I think it will be a public benefit if the old and singular custom of rearing childien to the constant use of one hand, to the prejudice of the other, were totally 
abolished, and the alternate use of both in ' which the rich enjoyed; then it was contheir various occunations universally sub- | sidered no disgrace for such able surgeons stituted. The advantages derivahle from as the late Mr. Hey, of Leeds, and other's such a regulation, connected with various, as hmmane and experienced as hinself, to circumstances and accidents, require no attend the poor; and we rarely heard of details If you will give publicity to this any instances of ignorance and neglect in suggestion in your useful LAxcet, you the discharge of duties upon which it was may be the means of creating millions of considered honourable to enter. No ambidexters. I remain, Sir, yours, \&c. JANES SMethurst.

South Lamheth, Surrey, Narch 29th, 1834. sooner did that vicious Act come into operation than a host of ignorant apothecaries presented themselves at parish meetings, and, introducing their trading propensities, succeeded in monopolizing, as they now do, almost all the parishes in the king-

\section{MEDICAL REFORAT.}

THE APOTHECARIES ACT.-PARTSH MEDICAL CONTRACTS. - MEDICAL CHARTTIES.-PROFESSTON

\section{To the Elitor of THE LANCET.}

Str, $-I$ beg through your widely cir. culated periodical to congratulate the profession on the subject of merical reform being at length taken up hy the legislature, under the direction of $\mathrm{Mr}$. Warburton and Mr. Hume. At the same time I hope your atiention will be directed to some of the observations, which appear to have escaped your notice, made by Colonel Wood, in opposition to the appointment of a select committee. The following remarks to which I refer are extracted from the St.Janes's Chronicle, dated Feb. IIth: respectable niembers of the profession.

"The Apothecaries Act, of which the The impositions practised on the Worhon. Nember complained, was passed in shipful Company are a sufficient proof that 1815, and, in his" (Col. Wood's) "opinion their " strict exaninations," as Colonel deserved the title of the Poor Man's Act. It Wood calls them, are more alaptad for was in the power of the rich, when af - taking fees from the starving candidate flicted with illness, to procure for them- than for the good of the community. selves the best medical advice, but the Since the year 1815 , an apprenticeship to poor must be content with such assistance a chemist and druggist, together with a as the parish provided for them. The certain legree of eifirontery, have bcen Apothecaries Act then, by requiring every found just as valuable a passport into the practitioner to undergo a strict examination, afforded to the poor every possible protection against the employment of quacks and ignorant men as parish surgeans."

Of all the "ignorant" measures ever sanctioned by law, I have no hesitation in asserting, that this Act has been found the most injurions to the interests of the poor, by almost entirely depriving them of the benefits of suryical skill. Before its enactment no one ever heard of anatomical pursuits being lisconraged, Jecanse the exhumation of dead bodies was illegal, and few practitioners were considered eli- have ventured to usurp the title and office gible to the appointment of parish suryeon, of a surgeon without their diploma; he who did not possess a competent know- would have been compelled to pursue his ledge of anatomy and suryery, and a di-' appropriate occupation of pharmacopolsst pioma from one of the Royal Colleges of and dispenser. Such a salutary regulaSurgeons. Then the parochial poor par- tion, however, would not have accorded ticipated in general in the same benefits with the views and practices prevailing 